\title{
OROIASIOH
}

Available online at Website http://ejournal.undip.ac.id/index.php/rotasi

\section{PERANCANGAN MESIN PRODUKSI TEPUNG IKAN}

\author{
Ahmad Seng \\ Program Studi Teknik Mesin, Fakultas Teknik, Universitas Khairun \\ Kampus II Gambesi Ternate Selatan \\ E-mail: ahmadseng@yahoo.com, amseng@unkhair.ac.id
}

\begin{abstract}
ABSTRAK
Sektor industri merupakan sektor yang sangat potensial untuk pengembangan sumber daya manusia yang ada di tanah air. Berbagai industri telah dikembangkan terutama dalam industri permesinan, mulai dari yang menggunakan mesin dengan sistem kontrol sampai pada industri yang masih menggunakan campur tangan manusia (manual).Persaingan dibidang industri mendorong timbulnya revolusi dibidang industri yang dalam pelaksanaannya memerlukan perkembangan dalam bidang permesinan, serta keinginan manusia untuk memproduksi dengan cepat, efektif, dan ekonomis, menjadi dasar pengembangan mesin-mesin produksi. Kemajuan yang pesat dari mesin perkakas mendesak segala bentuk pekerjaan tangan yang lambat menjadi cepat dan efektif. Dari uraian latar belakang masalah yang dikemukakan diatas, maka penulis dapat merumuskan suatu rumusan masalah sebagai berikut: 1) Bagaimana cara atau proses pembuatan alat produksi tepung ikan 2)Bagaimana proses kerja mesin produksi tepung ikan yang efisien. 3)Bagaimana meningkatkan hasil produksi dan memajukan industri kecil dan menengah di Indonesia. Adapun tujuan penelitian yang diharapkan adalah: 1) Mengetahui kapasitas alat produksi tepung ikan. 2)Membuat alat produksi tepung ikan mekanis. Kesimpulan dari hasil penelitian yang telah dilakukan, maka 1) 3kg ikan kering diolah dalam waktu 10,46 menit menghasilkan tepung ikan seberat 1,9 Kg. 2) Dari hasil penelitian diatas dapat diketahui kapasitas (Q) dari mesin tepung ikan ini yaitu 17,19 Kg / Jam. 3) Efesiensi alat tepung ikan setelah diuji adalah 66,7 \%. 4) Persentase ikan yang tidak jadi tepung ikan setelah diuji dalah 33,3\%. 5). Dalam pembuatan alat produksi tepung ikan, semakin rapat jarak pisau maka semakin halus tepung ikan yang dihasilkan. 6) Dari hasil pengambilan data pengujian mesin tepung ikan didapat bahwa semakin sedikit ikan yang dimasukkan kedalam tangki penggilingansemakin cepat putaran yang terjadi.
\end{abstract}

Kata kunci: Perancangan Mesin, Tepung Ikan

\section{PENDAhUluan}

Sumber daya manusia berkualitas adalah salah satu aset paling berharga bagi suatu bangsa dalam era perkembangan dunia usaha yang semakin kompleks dan penuh persaingan terutama dalam era globalisasi dewasa ini.Sektor industri merupakan sektor yang sangat potensial untuk pengembangan sumber daya manusia yang ada di tanah air. Berbagai industri telah dikembangkan terutama dalam industri permesinan, mulai dari yang menggunakan mesin dengan sistem kontrol sampai pada industri yang masih menggunakan campur tangan manusia (manual).Persaingan dibidang industri mendorong timbulnya revolusi dibidang industri yang dalam pelaksanaannya memerlukan perkembangan dalam bidang permesinan, serta keinginan manusia untuk memproduksi dengan cepat, efektif, dan ekonomis, menjadi dasar pengembangan mesin-mesin produksi. Kemajuan yang pesat dari mesin perkakas mendesak segala bentuk pekerjaan tangan yang lambat menjadi cepat dan efektif. Proses alat produksi tepung ikan berkembang dengan pesatnya, seiring dengan perkembangan zaman. Proses produksi tepung ikan yang dimulai kurang lebih 2000 tahun sebelum masehi sampai pada era millenium ke tiga ini, dan terus mengalami perkembangan, mulai dengan cara manual sampai menggunakan mesin otomatis.

\section{PERMASALAHAN}

Dari uraian latar belakang masalah yang dikemukakan diatas, maka penulis dapat merumuskan suatu rumusan masalah sebagai berikut:

1) Bagaimana cara atau proses pembuatan alat produksi tepung ikan.

2) Bagaimana proses kerja mesin produksi tepung ikan yang efisien.

3) Bagaimana meningkatkan hasil produksi dan memajukan industri kecil dan menengah di Indonesia.

\section{TUJUAN PENELITIAN}

Adapun tujuan penelitian yang diharapkan adalah:

1) Mengetahui kapasitas alat produksi tepung ikan.

2) Membuat alat produksi tepung ikan mekanis.

Pembuatan alat produksi tepung ikan ini dimaksudkan agar nantinya dapat diproduksi dan digunakan oleh industri kecil ataupun industri menengah. 


\section{LANDASAN TEORI}

Suatu persoalan perencanaan bukanlah suatu persoalan hepotesis. Perencanaan mempunyai maksud yang asli suatu kreasi untuk mendapatkan suatu hasil akhir dengan mengambil suatu tindakan yang jelas, atau suatu kreasi atas sesuatu yang mempunyai kenyataan fisik.Perencanaan mesin, berarti perencanaan suatu sistem dan segala yang berkaitan dengan sifat mesin-mesin, produk, struktur, alat-alat dan instrument. Pada umumnya perencanaan mesin mempergunakan matematika, ilmu bahan, dan ilmu mekanika teknik.

\section{DASAR PEMBUATAN TEPUNG IKAN}

Cara membuat tepung ikan yang paling sederhana adalah dengan mencincang ikan dan mengeringkannya dibawah sinar matahari sehingga kadar airnya kurang dari 10\%, kemudian menumbuknya. Tepung ikan akan bermutu baik, bila bahan mentah yang dipakai adalah ikan yang tidak berlemak (lean fish). Jika bahan mentahnya adalah ikanikan berlemak (fatty fish), tepung ikan yang dihasilkan biasanya banyak mengandung lemak. Hal ini merugikan sebab oksidasi lemak akan mengakibatkan tepung ikan mudah mengalami ketengikan (rancidity). Kalaupun bahan baku pembuatan tepung ikan adalah ikan berlemak, bahan baku tersebut harus dimasak. Selama pemasakan, protein akan menggumpal dan sel ikan yang mengandung lemak akan pecah, sehingga setelah dipisahkan dari air akan didapat hasil sampingan berupa minyak ikan.Dalam proses tersebut biasanya bagian padat yang ikut terbuang mencapai $20 \%$. Dengan demikian, mutu tepung ikan yang dihasilkan rendah.

\section{KOMPOSISI TEPUNG IKAN}

Komposisi tepung ikan tidak saja tergantung pada spesies ikan yang digunakan, tetapi juga dipengaruhi oleh bentuk dan kulialitas bahan baku yang digunakan. Adapun komposisi tepung ikan adalah sebagai berikut:

Tabel 1. Kandungan Nutrisi dalam Tepung ikan

\begin{tabular}{cc}
\hline Komposisi nutrisi & Persentase jumlah \\
\hline Protein & $60-75$ \\
Lemak & $6-14$ \\
Kadar air & $4-12$ \\
\hline
\end{tabular}

Sumber balai penelitian teknologi perikanan (Referensi 10)

\section{PEMANFAATAN TEPUNG IKAN}

Kegunaan utama tepung ikan adalah sebagai bahan campuran makanan ikan atau ternak lain. Karena kandungan proteinnya yang tinggi dan komposisi asam aminonya pun cukup seimbang, tepung ikan merupakan bagian penting terutama untuk pakan ayam, dan ikan. Bahkan, berdasarkan hasil percobaan yang telah dilakukan oleh balai penelitian teknologi perikanan tahun 1989, ternyata ikan dapat tumbuh lebih cepat bila dalam makanannya ditambah tepung ikan sebesar $10-40 \%$.

\section{POROS}

Poros merupakan salah satu bagian yang terpenting dari setiap mesin. Hampir semua mesin meneruskan tenaga bersama-sama dengan putaran utama dalam transmisi seperti itu dipegang oleh poros.

Poros untuk meneruskan daya diklasifikasikan menurut pembebanannya sebagai berikut:

- Poros transmisi (line shaft)

Poros ini mendapat beban puntir dan lentur. Daya ditransmisikan kepada poros ini melalui kopling, roda gigi, puli, sabuk, rantai dan lain-lain.

- Spindel (spindle)

Poros yang pendek, seperti poros utama mesin perkakas, dimana beban utamanya berupa puntiran. Syarat yang dipenuhi poros ini adalah deformasinya harus kecil dan bentuk serta ukurannya harus teliti.

- Gandar (axle)

Poros ini dipasang diantara roda-roda kereta api, dimana tidak mendapat beban puntir, dan tidak berputar. Gandar ini hanya mendapat beban lentur, kecuali jika digerakkan oleh penggerak mula dimana akan mengalami beban puntir juga.

- Poros (shaft)

Poros yang ikut berputar untuk memindahkan daya dari mesin ke mekanisme yang digerakkan. Poros ini mendapat beban puntir murni dan lentur.

- Poros luwes

Poros yang berfungsi untuk memindahkan daya dari dua mekanisme, dimana perputaran poros membentuk sudut dengan poros lainnya

\section{POROS DENGAN BEBAN PUNTIR}

Jika diketahui bahwa poros yang akan direncanakan tidak mendapat beban lain kecuali torsi, maka diameter poros tersebut dapat lebih kecil dari pada yang dibayangkan. Meskipun demikian, jika diperkiraan akan terjadi 
pembebanan berupa lenturan, tarikan atau tekanan, misalnya jika sebuah sabuk, rantai atau roda gigi dipasangkan pada poros motor, maka kemugkinan adanya pembebanan tambahan tersebut perlu diperhitungkan dalam factor keamanan yang diambil.

Jika $P$ adalah daya nominal output dari motor penggerak, maka berbagai macam factor keamanan biasanya dapat diambil dalam perencanaan, sehingga koreksi pertama dapat diambil kecil. Jika factor koreksi adalah $f c$ (lampiran Tabel 3) maka daya rencana $P d(\mathrm{~kW})$ sebagai patokan adalah:

$P d=f c . P(\mathrm{~kW})$ *2.1 Referensi (7)

Jika daya diberikan dalam daya kuda (PS), maka harus dikalikan dengan 0,735 untuk mendapatkan daya dalam kilo watt $(\mathrm{kW})$.

Jika momen puntir (disebut juga sebagai momen rencana) adalah $T$ (kg.mm) maka:

$P d=\frac{(T / 1000)\left(2 \pi n_{1} / 60\right)}{102}$ *2.2 Referensi (6)

sehingga:

$T=9,7 \times 10^{5} \frac{p_{d}}{n_{1}}$ *2.3 Referensi (6)

Bila momen rencana $T$ (kg.mm) dibebankan pada suatu diameter poros $d_{s}(\mathrm{~mm})$, maka tegangan geser $\tau$ $\left(\mathrm{kg} / \mathrm{mm}^{2}\right)$ yang terjadi adalah

$$
\tau=\frac{T}{\left(\pi d_{s}^{3} / 16\right)}=\frac{5,1 T}{d_{s}^{3}}
$$

Tegangan geser yang diizinkan $\tau_{a}\left(\mathrm{~kg} / \mathrm{mm}^{2}\right)$ untuk pemakaian umum pada poros dapat diperoleh dengan berbagai cara.Di dalam buku ini $\tau_{a}$ dihitung atas dasar batas kelelahan puntir yang besarnya diambil $40 \%$ dari batas kelelahan tarik yang besarnya kira-kira $45 \%$ dari kekuatan tarik $\sigma_{B}\left(\mathrm{~kg} / \mathrm{mm}^{2}\right)$. Jadi batas kelelahan puntir adalah $18 \%$ dari kekuatan tarik $\sigma_{B}$, sesuai denagn standar ASME. Untuk harga 18\% ini factor keamanan diambil sebesar $1 / 0,18=5,6$ ini diambil untuk bahan SF dengan kekuatan yang dijamin, dan 6,0 untuk bahan S-C dengan pengaruh masa, dan baja paduan. Factor ini dinyatakan dengan $S f_{1}$. Selanjutnya ditinjau apakah poros tersebut akan diberi alur pasak atau dibuat bertangga, karena pengaruh konsentrasi tegangan cukup besar. Pengaruh kekasaran permukaan juga harus diperhitungkan perlu diambil factor yang dinyatakan sebagai $S f_{2}$ dengan harga sebesar 1,3 sampai 3,0. Dari hal-hal di atas maka besarnya $\tau_{a}$ dapat dihitung dengan

$$
\tau_{a}=\frac{\sigma B}{\left(S f_{1} \times S f_{2}\right)}
$$

Kemudian, keadaan momen puntir itu sendiri juga harus ditinjau. Faktor koreksi yang dianjurkan oleh ASME juga dipakai disini. Factor ini dinyatakan dengan Kt dipilih sebesar 1,0 jika beban dikenakan secara halus, 1,0-1,5 jika terjadi sedikit kejutan atau tumbukan, dan 1,5-3,0 jika beban dikenakan dengan kejutan atau tumbukan besar.Meskipun dari perkiraan sementara ditetapkan bahwa beban hanya terdiri atas momen puntir saja, perlu ditinjau pula apakah ada kemungkinan pemakaian dengan beban lentur dimasa mendatang. Jika memang diperkirakan akan terjadi pemakaian dengan beban lentur maka dapat dipertimbangkan pemakaian factor $\mathrm{Cb}$ yang harganya antara 1,2 - 2,3. (jika diperkirakan tidak akan terjadi pembebanan lentur maka $\mathrm{Cb}$ diambil =1,0). 
Dari persamaan (2.4) diperoleh rumus untuk menghitung diameter poros $d_{s}(\mathrm{~mm})$ sebagai berikut:

$d_{s}=\left[\frac{5,1}{\tau_{a}} K_{t} C_{b} T\right]^{1 / 3}$

*2.6 Referensi (6)

Diameter poros harus dipilih dari (Tabel 1.7 Referensi 6 [3]). Pada tempat diamana akan dipasang bantalan duduk, pilihlah suatu diameter yang lebih besar dari harga yang cocok didalam tabel untuk menyesuaikannya dengan diameter dari bantalan. Selanjutnya ukuran dan alur pasak dapat ditentukan ( Tabel 1.8 Referensi 6 [3]).Dalam pembuatan mesin tepung ikan ini poros yang digunakan terbuat dari baja karbon konstruksi mesin (JIS G 4501) S40C dengan diameter 1 " panjang $74 \mathrm{~cm}$.

\section{METODE PENELITIAN}

Tabel 2. Bahan dan Alat

\begin{tabular}{cll}
\hline No. & Bahan yang digunakan & Alat yang digunakan \\
\hline $\mathbf{1}$ & Besi plat 2 mm, dengan ukuran $80 \times 120 \mathrm{~cm}$ & 1. Mesin las listrik \\
$\mathbf{2}$ & Besi siku $40 \times 50$ & 2. Mesin las oksi-asitelin \\
$\mathbf{3}$ & Poros As 1 " & 3. Gurinda tangan \\
$\mathbf{4}$ & Bearing duduk 1 " & 4. Gergaji tangan \\
$\mathbf{5}$ & Ring & 5 . Mesin gergaji \\
$\mathbf{6}$ & Mur dan baut & 6. Mesin bubut \\
$\mathbf{7}$ & Pulli Alma B1 x 3" dan B1 x 12" & 7. Mesin frais \\
$\mathbf{8}$ & Sabuk- V Tipe B No. 68 & 8. Mesin bor tangan \\
$\mathbf{9}$ & Motor listrik 1 Hp, 2800 rpm & 9 . Catok \\
$\mathbf{1 0}$ & Spie & 10 . Kunci pas dan kunci ring pas \\
$\mathbf{1 1}$ & Kawat las & 11 . Rol meter \\
$\mathbf{1 2}$ & Cat & 12. Tachometer \\
$\mathbf{1 3}$ & Amplas & 13 . Palu \\
\hline
\end{tabular}

\section{Perlakuan dan Rancangan Penelitian / Kajian}

Urutan kegiatan yang dilakukan dalam penelitian ini adalah :

- Pembuatan Alat Penelitian

- Pengujian Alat

- Pengambilan dan Pengolahan Data

\section{PEMBUATAN ALAT PENELITIAN}

Pembuatan Rangka dan Meja

Pembuatan rangka dan meja dilakukan dengan menyiapkan besi siku dan plat kemudian dipotong sesuai ukuran yang telah ditentukan. Pemotongan dapat dilakukan dengan memakai gergaji dan penyambungan dilakukan dengan pengelasan sesuai desainnya.

\section{Pembuatan Tabung}

Tabung terbuat dari besi plat yang telah dilengkungkan kemudian dilas sesuai dengan ukuran yang telah dibuat dari bahan besi plat dan menggunakan gunting plat untuk memotong sesuai ukuran yang telah direncanakan. Gunakan bor untuk mengebor tempat baut, kemudian diamplas untuk fhinising.

\section{Pembuatan Poros}

Poros utama dibuat dengan merangkaikan bahan yang telah tersedia antara lain poros/as, pulli, spie dan bearing. Poros/as dibuat dengan menggunakan mesin bubut dan lubang tempat spie dibuat dengan menggunakan mesin frais. Transmisi pulli dapat dibuat dengan menggunakan mesin bubut sesuai ukuran yang telah ditentukan, dan spie dibuat dengan menggunakan mesin frais. Proses selanjutnya ialah pemasangan transmisi pulli, spie dan bearing duduk tempat dudukan poros/as.

\section{Perakitan Elemen-Elemen Mesin Tepung Ikan}

Perakitan yang dimaksud adalah penyambungan semua komponen alat mesin tepung ikan mulai dari rangka, meja, poros, tabung dan mesin penggerak menjadi satu bentuk kesatuan sesuai potongan komponennya, akan terbentuk alat produksi tepung ikan. 


\section{Finising}

Finishing atau pengerjaan akhir pada pembuatan alat tepung ikan yaitu dimulai dengan menggerinda semua komponen yang dianggap belum rata kemudian mengamplas permukaan tersebut dan sebagai proses akhir dari alat tersebut untuk memberikan nilai plus maka kami mengecetnya dengan menggunakan kompressor.

\section{PENGUJIAN ALAT}

Untuk mengetahui kemampuan dari alat yang dibuat, maka perlu diadakan pengujian. Dalam pengujian ini digunakan bahan baku sebagai media kerja adalah ikan yang telah dikeringkan sehingga kadar air yang terkandung pada ikan kurang dari $10 \%$.

Sedangkan peralatan yang digunakan untuk pengujian ini adalah stop watch, mistar, tachometer, alat tulis menulis dan alat produksi tepung ikan.

\section{Pengambilan data}

Dalam pengambilan data sebelum ataupun sesudah alat diukur, diamati, dan dihitung adalah:

a. Banyaknya bahan baku yang akan diproses $(\mathrm{kg})$.

b. Mencatat waktu perlakuan (menit).

c. Putaran poros (rpm)

d. Kemudahan operasi dan perawatan

\section{Pengolahan data}

Untuk mengetahui hasil operasi dari pada mesin ini, maka ada beberapa variabel yang perlu dihitung dan diketahui dalam pengolahan data.

Variabel tersebut antara lain:

1) Kapasitas (Q)

Besarnya kapasitas diukur berdasarkan banyaknya tepung ikan yang keluar dari mesin melalui lubang keluaran (outlet) persatuan waktu.

$$
\left.\mathrm{Q}=\frac{\text { berat ikan }}{\text { waktu pengolahan }}\right)
$$

2) Efisiensi alat $(\eta)$

Besarnya efisiensi alat adalah:

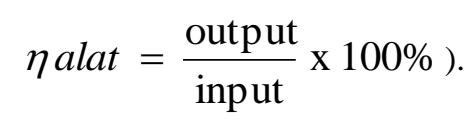

dimana:

$$
\begin{aligned}
& \text { Output = banyaknya hasil yang dicapai dalam proses }(\mathrm{kg}) \\
& \text { Input }=\text { banyaknya ikan yang diproses }(\mathrm{kg})
\end{aligned}
$$

3) Persentase ikan yang tidak jadi tepung ikan $(\mathrm{Pkr})$

Besarnya persentase ikan yang tidak jadi tepung dapat dihitung dengan persamaan 3.3 .

$\left.\mathrm{Pkr}=\frac{E}{F} \times 100 \%\right)$ *3.3 Referensi (10)

dimana:

$$
\begin{aligned}
& \mathrm{E}=\text { berat ikan yang tidak keluar lewat lubang keluaran } \\
& \mathrm{F}=\text { jumlah ikan yang diproses }
\end{aligned}
$$




\section{DIAGRAM ALIR PROSES PENELITIAN}

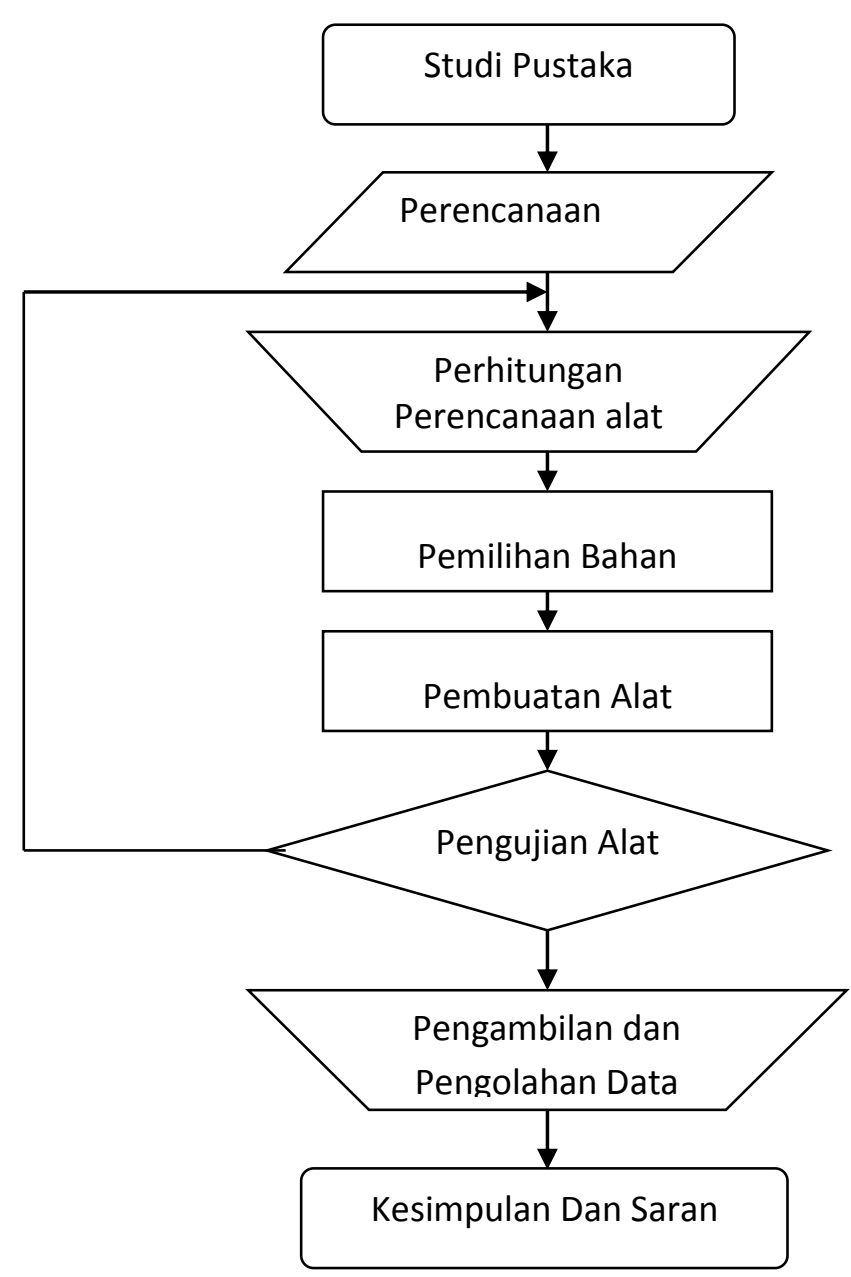

Gambar 1. Diagram Alir Penelitian

\section{DESAIN MESIN}

Mesin yang didesain adalah mesin tepung ikan. Dalam perencanaan mesin tepung ikan ini diusahakan mempunyai cara kerja yang sederhana dengan komponen sesedikit mungkin, disamping itu perencanaan mesin ini diharapkan mencerminkan suatu bentuk yang kompak, artinya disamping hemat dari segi penggunaan bahan, ruang, dan proses pembuatannya juga, bentuknya harus fungsional dan menarik. Adapun desain perencanaan dapat dilihat pada gambar 4.1. dan 4.2.

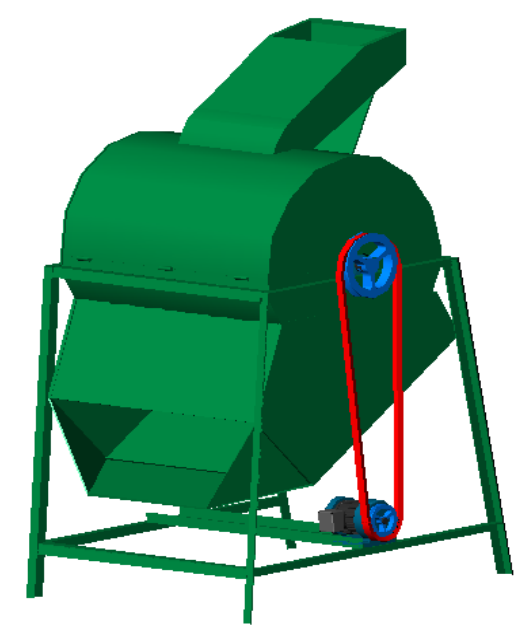

Gambar 2. Tampak Isometrik 


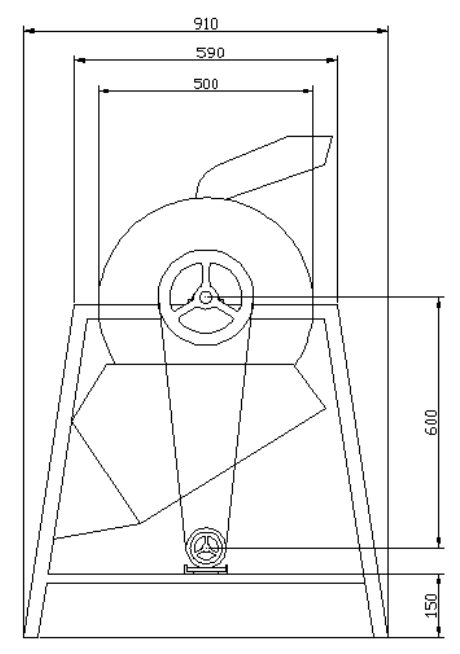

Gambar 2. Tampak Samping

\section{KAPASITAS DAN EFESIENSI ALAT}

Dalam penelitian ini mesin tepung ikan akan mengolah limbah ikan yang telah dikeringkan, menjadi tepung ikan. Untuk mengetahui kapasitas dan efesiensi hasil dari mesin tepung ikan adapun rumus yang digunakan adalah :

kapasitas mesin tepung ikan

besarnya kapaistas (Q) dapat diukur berdasarkan berat ikan keluar melalui lubang keluaran (outlet).

$\mathrm{Q}=\frac{\text { beratikan }}{\text { waktu pengolahan }}$

1) Pengujian dengan ikan kering seberat $0,5 \mathrm{Kg}$

$0,5 \mathrm{Kg}$ ikan kering diolah dalam waktu 1,57 menit,. menghasilkan tepung ikan seberat 0,4 Kg, sehingga:

$\mathrm{Q}=\frac{0,5}{1,57}$

$\mathrm{Q}=0,31 \mathrm{Kg} /$ menit

2) pengujian dengan ikan kering seberat $1,0 \mathrm{Kg}$

$1,0 \mathrm{Kg}$ ikan kering diolah dalam waktu 3,43 menit,. menghasilkan tepung ikan seberat 0,6 Kg, sehingga:

$\mathrm{Q}=\frac{1,0}{3,43}$

$\mathrm{Q}=0,29 \mathrm{Kg} /$ menit

3) pengujian dengan ikan kering seberat $1,5 \mathrm{Kg}$

$1,5 \mathrm{Kg}$ ikan kering diolah dalam waktu 5,46 menit,. menghasilkan tepung ikan seberat 0,9 Kg, sehingga:

$\mathrm{Q}=\frac{1,5}{5,46}$

$\mathrm{Q}=0,27 \mathrm{Kg} /$ menit

Dari hasil penelitian diatas dapat diketahui kapasitas $(\mathrm{Q})$ dari mesin tepung ikan ini yaitu:

$$
\mathrm{Q}=\frac{0,5+1,0+1,5}{1,57+3,43+5,46}
$$




$$
\begin{aligned}
& =\frac{3,0}{10,49} \\
& =0,28 \mathrm{Kg} / \text { menit }
\end{aligned}
$$

Apabila mesin ini dijalankan selama satu jam maka tepung ikan yang dapat dihasilkan adalah 0,28 x 60 = 17,19 Kg/Jam

\section{Efesiensi alat tepun ikan}

Besarnya efesiensi alat adalah:

$\eta_{\text {alat }}=\frac{\text { Output }}{\text { Input }} \times 100 \%$

1) Efesiensi dengan ikan kering seberat $0,5 \mathrm{Kg}$

Output adalah hasil olahan: $0,4 \mathrm{Kg}$

Input adalah banyaknya ikan yang diolah: $0,5 \mathrm{Kg}$

Sehingga:

$$
\begin{aligned}
\eta_{\text {alat }} & =\frac{0,4}{0,5} \times 100 \% \\
& =80 \%
\end{aligned}
$$

2) Efesiensi dengan ikan kering seberat $1,0 \mathrm{Kg}$

Output adalah hasil olahan: $0,6 \mathrm{Kg}$

Input adalah banyaknya ikan yang diolah: $1,0 \mathrm{Kg}$

Sehingga:

$$
\begin{aligned}
\eta_{\text {alat }} & =\frac{0,6}{1,0} \times 100 \% \\
& =60 \%
\end{aligned}
$$

3) Efesiensi dengan ikan kering seberat $1,5 \mathrm{Kg}$

Output adalah hasil olahan: $0,9 \mathrm{Kg}$

Input adalah banyaknya ikan yang diolah: $1,5 \mathrm{Kg}$

Sehingga:

$$
\begin{aligned}
\eta_{\text {alat }} & =\frac{0,9}{1,5} \times 100 \% \\
& =60 \%
\end{aligned}
$$

Dari hasil penelitian diatas dapat dapat diketahui efesiensi dari mesin tepung ikan ini yaitu:

$$
\begin{aligned}
\eta_{\text {alat }} & =\frac{80+60+60}{3} \\
& =66,7 \%
\end{aligned}
$$

Efesiensi alat tepung ikan adalah $66,7 \%$

Persentase ikan yang tidak jadi tepung ikan

Besarnya persentase ikan yang tidak jadi tepung dapat dihitung dengan persamaan 3.3.

$\left.\mathrm{Pkr}=\frac{E}{F} \times 100 \%\right)$

dimana:

$\mathrm{E}=$ Berat ikan yang tidak keluar lewat lubang keluaran (outlet)

$\mathrm{F}=$ Jumlah ikan yang diproses 
1) Persentase ikan yang tidak jadi tepung dengan ikan kering seberat $0,5 \mathrm{Kg}$

$\mathrm{E}=0,1 \mathrm{Kg}$

$\mathrm{F}=0,5 \mathrm{Kg}$

$$
\begin{aligned}
\mathrm{Pkr} & =\frac{0,1}{0,5} \times 100 \% \\
& =20 \%
\end{aligned}
$$

2) Persentase ikan yang tidak jadi tepung dengan ikan kering seberat $1,0 \mathrm{Kg}$

$$
\mathrm{E}=0,4 \mathrm{Kg}
$$

$\mathrm{F}=1,0 \mathrm{Kg}$

$$
\begin{aligned}
\mathrm{Pkr} & =\frac{0,4}{1,0} \times 100 \% \\
& =40 \%
\end{aligned}
$$

3) Persentase ikan yang tidak jadi tepung dengan ikan kering seberat $1,5 \mathrm{Kg}$

$\mathrm{E}=0,6 \mathrm{Kg}$

$\mathrm{F}=1,5 \mathrm{Kg}$

$$
\mathrm{Pkr}=\frac{0,6}{1,5} \times 100 \%
$$$$
=40 \%
$$

Dari hasil perhitungan diatas dapat diketahui Persentase ikan yang tidak jadi tepung dari mesin tepung ikan yaitu:

$$
\begin{aligned}
\mathrm{Pkr} & =\frac{20+40+40}{3} \\
& =33,3 \%
\end{aligned}
$$

Persentase ikan yang tidak jadi tepung ikan adalah $37 \%$

Tabel 3. Data Penelitian Tepung Ikan

\begin{tabular}{cccccc}
\hline Beban $(\mathrm{kg})$ & Putaran Poros (rpm) & Putaran Motor $(\mathrm{rpm})$ & Waktu (menit) & Hasil Olahan $(\mathrm{kg})$ & Sisa Olahan $(\mathrm{kg})$ \\
\hline 0.5 & 650 & 2500 & 1,57 & 0,4 & 0,1 \\
1,0 & 630 & 2000 & 3,43 & 0,6 & 0,4 \\
1,5 & 620 & 1960 & 5,46 & 0,9 & 0,6 \\
\hline
\end{tabular}

Tabel 4. Hasil Penelitian Tepung Ikan

Kapasitas (Q) (kg/jam) $\quad$ Efesiensi alat (\%) $\quad$ Persentase ikan yyg tdk keluar (\%)

$17 \quad 66,7 \quad 33,7$

\section{KESIMPULAN}

1) Dari hasil penelitian yang telah dilakukan, $3 \mathrm{~kg}$ ikan kering diolah dalam waktu 10,46 menit menghasilkan tepung ikan seberat $1,9 \mathrm{Kg}$.

2) Dari hasil penelitian diatas dapat diketahui kapasitas (Q) dari mesin tepung ikan ini yaitu $17,19 \mathrm{Kg} / \mathrm{Jam}$

3) Efesiensi alat tepung ikan setelah diuji adalah $66,7 \%$.

4) Persentase ikan yang tidak jadi tepung ikan setelah diuji dalah 33,3\% Dari hasil penelitian yang dilakukan dalam pembuatan alat produksi tepung ikan, semakin rapat jarak pisau maka semakin halus tepung ikan yang dihasilkan.

5) Dari hasil pengambilan data pengujian mesin tepung ikan didapat bahwa semakin sedikit ikan yang dimasukkan kedalam tangki penggilingansemakin cepat putaran yang terjadi.

\section{DAFTAR PUSTAKA}

1. B.H. Amstead, Phillip F.Ostwald, Myron L. Begeman, Teknologi Mekanik Jilid 2 Edisi ketujuh Versi S1, Erlangga, 1990.

2. Daryanto, MesinPerkakasBengkel, Penerbit Rineka Cipta, Jakarta, 2002.

3. Geoffrey,Boothroyd, School Of Engineering DepartemenT Of Mechanical And Aerospace Engineering University Of Massa Chussetts, "Fundamentals Machining And Machine Tools", 1975.

4. Harsanto, Motor Bakar Cetakan Ketujuh, Penerbit Djambatan, Jakarta, 1984. 
5. Joseph E. Shigley, Larry D. Mitchell, Gandhi Harahap, Perencanaan Teknik Mesin Edisi Keempat Jilid I, Erlangga, 1986.

6. Sularso, Kiyokatsu Suga, Dasar Perencanaan dan Pemilihan Elemen Mesin, PT. Pardnya Paramitha, Jakarta, 1987.

7. Syamsir A. Muin, Dasar-dasar Perencanaan Perkakas Dan Mesin-Mesin Perkakas, CV. Rajawali, Jakarta, 1989.

8. Umar Sukrisno, Bagian-Bagian Mesin Dan Merencana, Penerbit Erlangga, Jakarta, 1984.

9. Zainun Achmad, Elemen mesin I, PT. Refika Aditama, Bandung, 1999.

10. Eddy Afrianto. Ir, Evi Liviawaty. Ir, Pengawetan Dan Pemgolohan Ikan, Penerbit Kanisius, Jogjakarta, 1989.

\section{LAMPIRAN}

\section{1) Dokumentasi Pengujian alat}
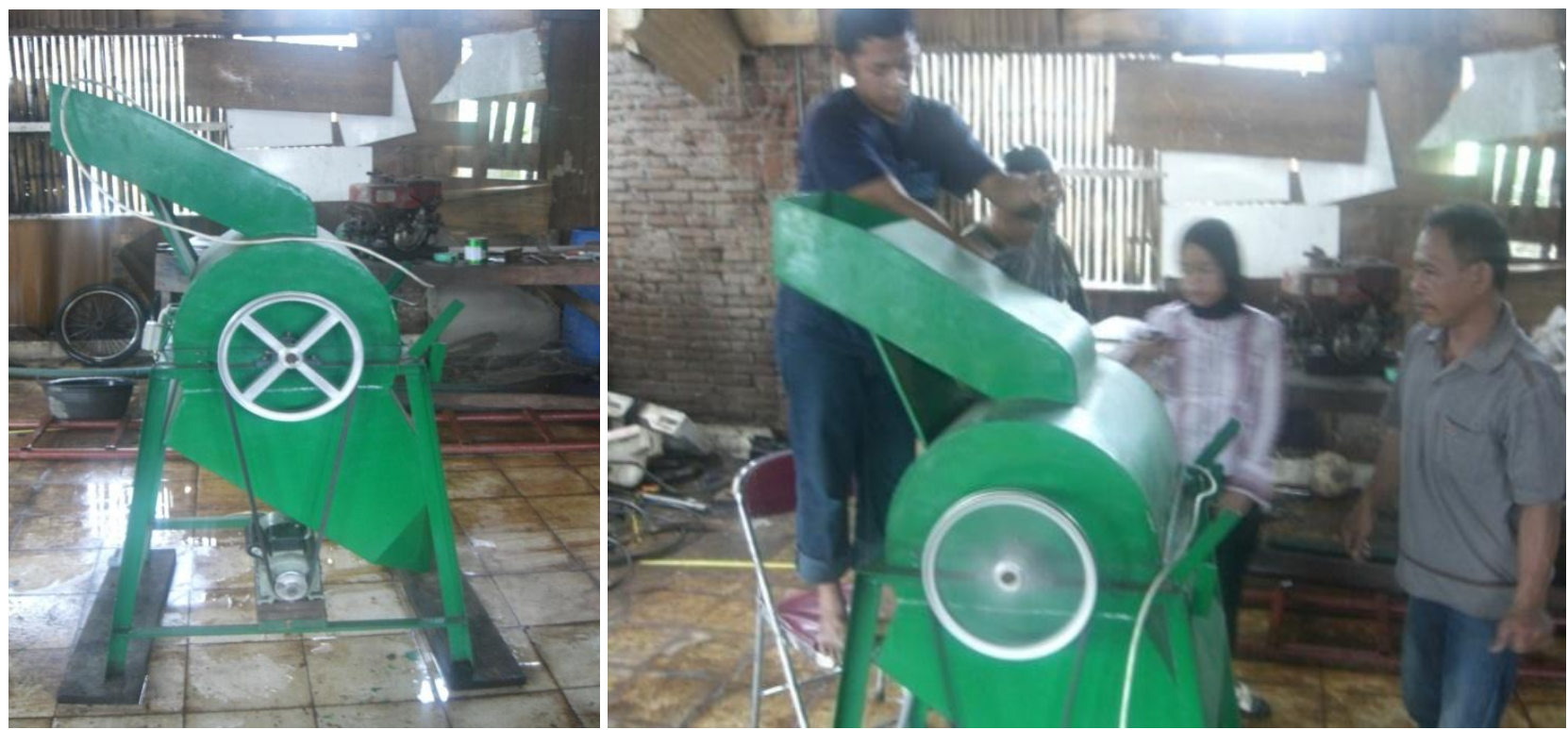

Proses pengujian

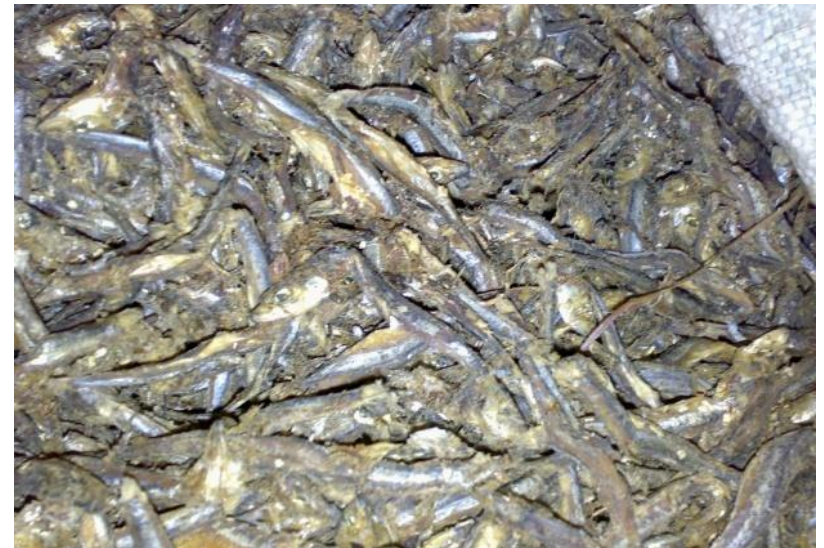

Bahan baku

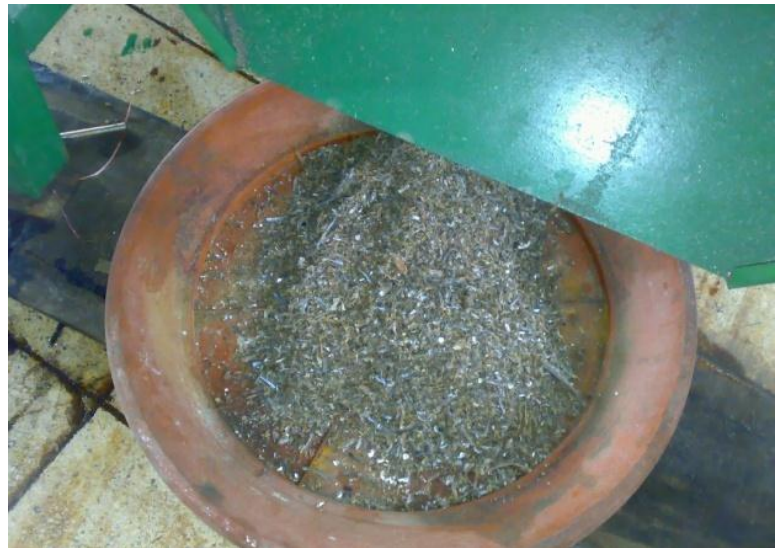

Hasil Olahan 


\section{2) Lampiran Tabel}

Tabel 1.7 Diameter poros.

(Satuan mm)

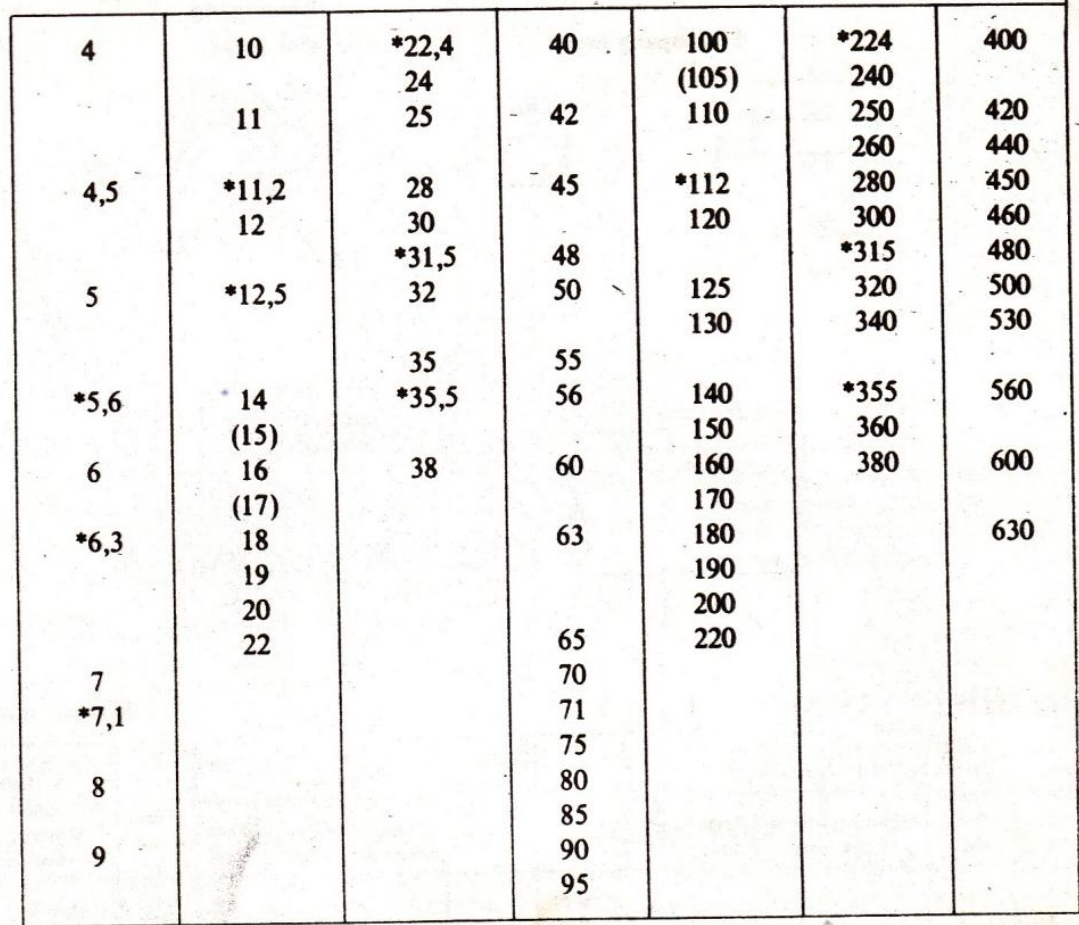

Keterangan : 1. Tanda* menyatakan bahwa bilangan yang bersangkutan dipilih dari bilanga standar.

2. Bilangan di dalam kurung hanya dipakai untuk bagian dimana akan dipasang bantalan gelinding.

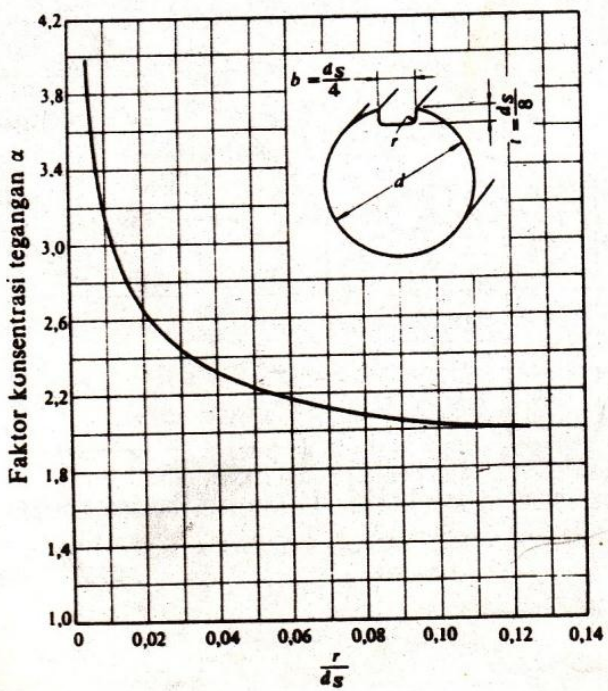

Gbr. 1.1 Faktor konsentrasi tegangan $\alpha$ untuk pembebanan puntir statis dari suat poros balat dengan alur pasak perseg yang diberi filet. 
Tabel 1.8 Ukuran pasak dan alur pasak.
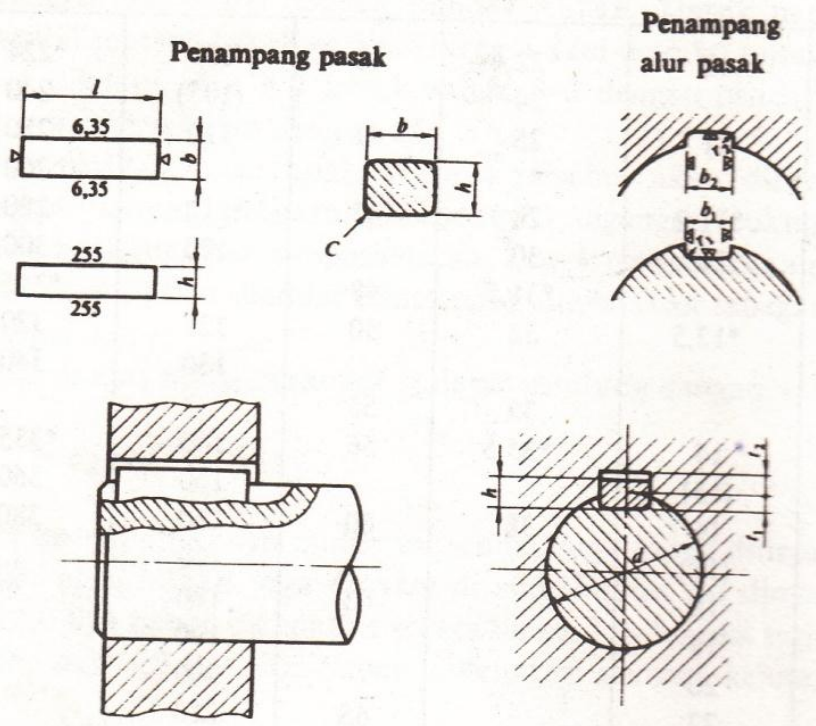

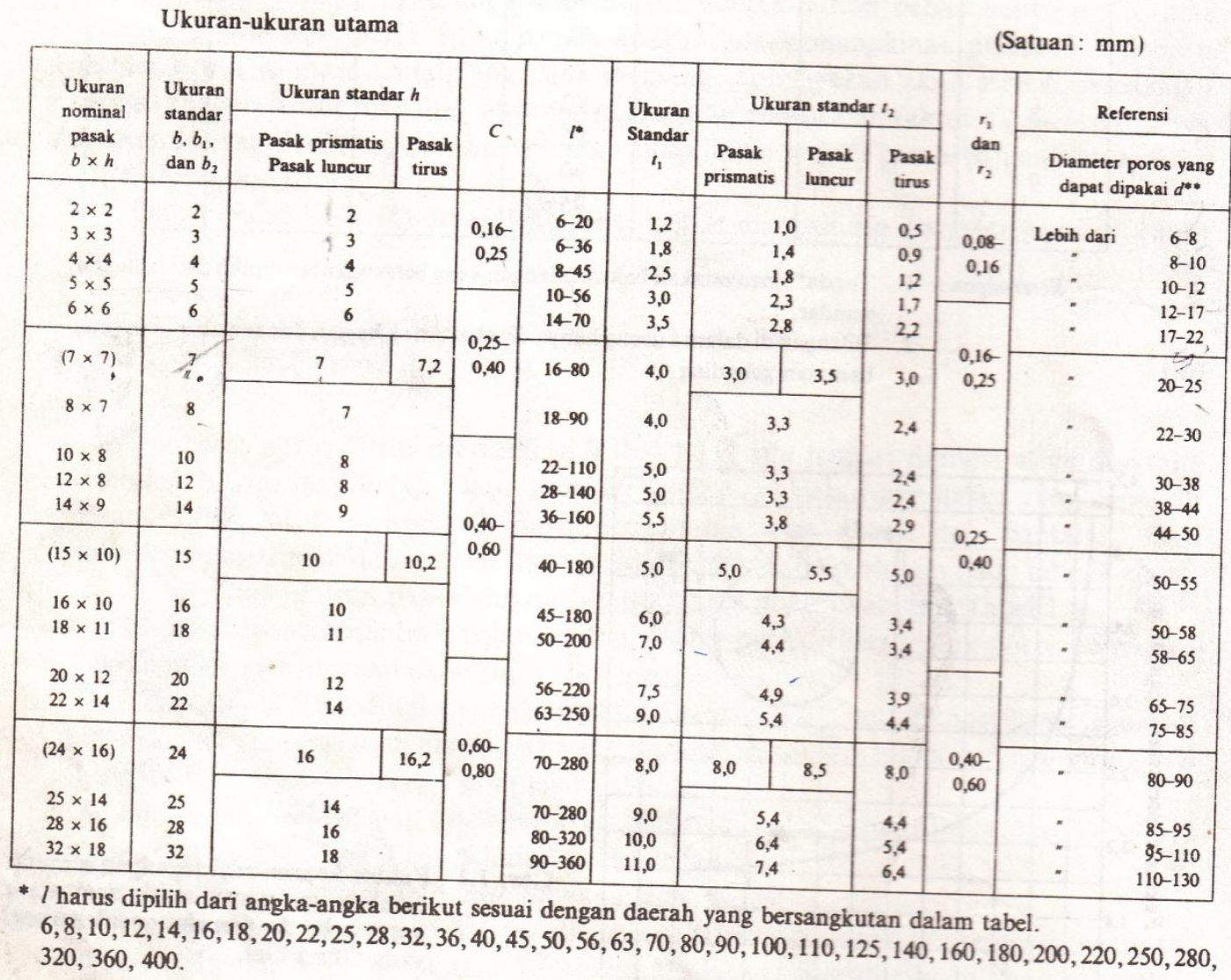

